(decomp.) $265^{\circ}$ (in the literature, $267^{\circ}$ (decomp.)), and by a mixed melting point comparison with an authentic synthetic specimen kindly presented by Dr. R. H. F. Manske. Finally, the ultra-violet absorption spectrum of the natural product coincided exactly with that of the synthetic material.<smiles>NCCc1c[nH]c2ccccc12</smiles>

(I)

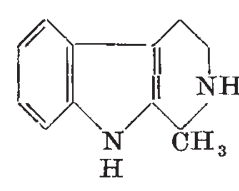

(II)

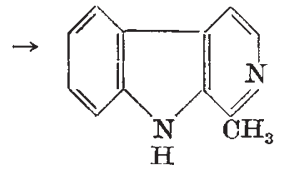

(III) casein supported this, since $\alpha$-amino- $n$-butyric acid was found in the alkaline, but not in the acid, hydrolysate, and the glycine spot on chromatograms of the alkaline hydrolysate was distinctly stronger than the corresponding spot on comparable chromatograms of the acid hydrolysate.

These findings led to a study of the effect of hot sodium and barium hydroxides on various amino-acids. Results so far obtained have shown that, under the conditions generally used for hydrolysis of proteins with alkali, threonine yields glycine and $\alpha$-amino- $n$-butyric acid, serine yields glycine and alanine, and cysteine and eystine yield alanine. An

Tetrahydroharman (II) does not seem to have been obtained previously from natural sources, and this proof of its occurrence in Nature is of interest in connexion with studies of the biogenesis of alkaloids. It has often been suggested ${ }^{3}$, for example, that harman (III) and related $\beta$-carboline alkaloids, are synthesized in the plant from tryptamine (I), or tryptophan, by condensation with acetaldehyde to give (II), and subsequent dehydrogenation to (III). Tryptamine (I) has already been shown ${ }^{4}$ to occur in several species of the genus Acacia (Leguminosæ), and $\mathrm{G}$. Hahn and H. Ludewig ${ }^{5}$ have demonstrated that tryptamine readily condenses with acetaldehyde in vitro and under 'physiological' conditions of temperature and $p H$. Harman (III) has, of course, been isolated from several plants ${ }^{6}$, and the present isolation of tetrahydroharman (II) from a natural source completes the series and supports the speculations of Robinson and others ${ }^{3}$ in a very satisfactory way.

Note added on July 19. It has recently been announced ${ }^{7}$ that racemic tetrahydroharman has also been isolated from Eloxgnus augustifolia.

G. M. BADGER

A. F. BeEcham

Johnson Chemical Laboratories,

University of Adelaide. April 30.

${ }^{1}$ Australian Phytochemical Survey. Pt. 1. Bull. No. 241, Commonwealth Scientiflc and Industrial Research Organization (Melbourne, 1949).

2 Tatsui, G., J. Pharm. Soc. Japan, 48, 453 (1928); Chem. Abs, 22, 3415 (1928).

${ }^{3}$ Perkin, W. H., and Robinson, R., J. Chem. Soc., 115, 933, 967 (1919). Kermack, W. O., Perkin, W. H., and Robinson, ibid., 119, 1602 (1921). Robinson, R., ibid., 111, 876 (1917) 1079 (1936). Congress Lecture, First Inter. Cong. Biochem. Cambridge, 1949. Schöpf, C., Angew. Chem., 50, 779, 797 (1937). ${ }^{4}$ White, E. P., N.Z. J. Sci. Tech., 25 B, 137 (1944).

'Ber., 6', 2031 (1934).

"See Henry, T. A., "The Plant Alkaloids", 4th edit. (J. and A. Churchill, London, 1949).

"Men'shikov, G. P., Gurevich, E. I., and Samsonova, G. A., Zhur Obshchei Khim. (J. Gen. Chem.), 20, 1927 (1950); Chem. Abst.,
45, 2490 (1951).

\section{Alkaline Decomposition of Amino-acids}

IN the course of an examination of the amino-acid composition of soil hydrolysates by the paper chromatography technique, it was noticed that alkaline hydrolysates of soil contained greater amounts of $\alpha$-amino- $n$-butyric acid than did acid hydrolysates ${ }^{1}$. Further work indicated that alkaline hydrolysates also contained greater amounts of glycine. These results suggested that, under the conditions commonly employed for the hydrolysis of proteins with alkali, glycine and $\alpha$-amino- $n$-butyric acid are formed by decomposition of other amino-acids. Paper chromatographic examination of acid ( $6 \mathrm{~N}$ hydrochloric acid) and alkaline ( $5 \mathrm{~N}$ sodium hydroxide) hydrolysates of attempt is now being made to follow these decompositions quantitatively. Preliminary results indicate that, after treatment of threonine with $5 \mathrm{~N}$ sodium hydroxide in a sealed tube at $105^{\circ} \mathrm{C}$. for $24 \mathrm{hr}$., about $1-3$ per cent of the original threonine nitrogen is present as $\alpha$-amino- $n$-butyric acid and $60-70$ per cent as glycine.

Full details of this work will be published later. J. M. BREMNeR

Rothamsted Experimental Station, Harpenden, Herts. May 9.

${ }^{1}$ Bremner, J. M., Biochem. J., 47, 538 (1950).

\section{Dielectric Properties of a Sample of Deuterium Chloride containing an Impurity}

Following a fairly extensive study of the dielectric properties of solid hydrogen chloride in this Laboratory ${ }^{2}$, it was proposed to investigate the deuterated form. While hydrogen chloride was prepared by action of strong sulphuric acid on sodium chloride, deuterium chloride was obtained by dropping heavy water on thionyl chloride, the other product of the reaction being sulphur dioxide.

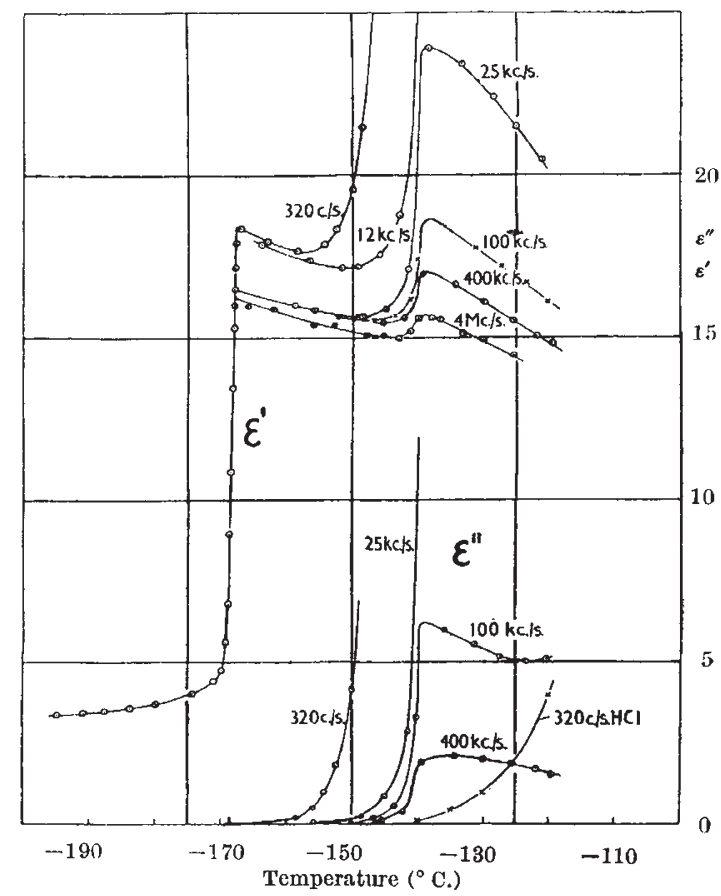

